\title{
Undersowing wheat with different living mulches in a no-till system. II. Competition for light and nitrogen
}

\author{
Matthieu CAROF ${ }^{\mathrm{a}}$, Stéphane de TourdonNET ${ }^{\mathrm{a} *}$, Patrick SAUlas $^{\mathrm{b}}$, Dominique LE FlOch $^{\mathrm{a}}$, Jean RogER-ESTRADE ${ }^{\mathrm{a}}$ \\ a AgroParisTech, UMR211, INRA/AgroParisTech, 78850 Thiverval-Grignon, France \\ ${ }^{\mathrm{b}}$ INRA, UMR211, INRA/AgroParisTech, 78850 Thiverval-Grignon, France
}

(Accepted 22 March 2007)

\begin{abstract}
No-till wheat management systems with a living mulch is a possible means to improve agricultural sustainability. Nonetheless living mulches may affect wheat production by competition for light and nutrients. Therefore, here we studied competition for light and nitrogen between wheat and different living mulches under no-till. We grew wheat using three different practices: (1) conventionally-tilled wheat, (2) no-till wheat and (3) wheat undersown with various living mulches. Living mulches were: red fescue, sheep's fescue, alfalfa, bird'sfoot-trefoil, black medic, and white clover. We measured: leaf area index and height of wheat and living mulch, and radiation partitioning between species; above-ground biomass of wheat and living mulch; nitrogen uptake of wheat and living mulch; and wheat nitrogen status using a nitrogen nutrition index. Our results showed that at flowering, competition for light between mixed species occurred in sixteen out of the eighteen situations, i.e. in three experiments times six no-till/living mulch treatments. Further, the biomass of wheat grown with living mulches was $24-84 \%$ lower than no-till wheat alone. At flowering, competition for nitrogen only occurred in seven out of the eighteen situations. Our findings showed that competition for light was due to light partitioning between mixed species. Furthermore, we found that the light competitive ability of wheat undersown with a living mulch was the highest when wheat was much taller than living mulch, and also when wheat leaf area in the mixed canopy layer was greater than that of living mulch. We conclude that the negative effects of living mulches on wheat yield should be solved by a careful choice of living mulch species and the control of living mulches by mechanical or chemical means.
\end{abstract}

no-tillage / undersowing / winter wheat (Triticum aestivum L.) / leguminous and grass living mulches / interspecific competition / canopy structure / radiation partitioning / nitrogen status

\section{INTRODUCTION}

Use of no-till management systems for cropping winter wheat (Triticum aestivum L.) provides some economical and environmental advantages to agriculture (Hernánz et al., 1995; Basic et al., 2004). Nevertheless, these management systems may present some short-term drawbacks, e.g. no-tillage may induce an increase in herbicide use (Sánchez-Gíron et al., 2004) and/or a decrease in soil physical quality (Lampurlanés and Cantero-Martínez, 2003). Undersowing no-till wheat with a living mulch may overcome, at least partially, drawbacks of no-tillage. Living mulch is a plant species (annual or perennial) that is grown with the cash crop and is maintained on the field even during the off-growing season (Hartwig and Ammon, 2002). A living mulch has been shown to take up excess soil nutrients, enhance soil physical characteristics, improve weed and pest control, and increase biological diversity (Hartwig and Ammon, 2002; Nakamoto and Tsukamoto, 2006). Few studies have considered the effects on wheat of no-till management systems with a living mulch. On the one hand, a living mulch can compete for light, nutrients, and/or water with the cash crop and weeds (Teasdale, 1996). If this competition is expected to suppress weeds, it can also lower cash crop yield. On the other hand, mixed species may use

\footnotetext{
*Corresponding author: stephane.de_tourdonnet@agroparistech.fr
}

different ecological niches if they have different resource requirements in time or space (Vandermeer, 1989). Furthermore, one crop can provide resources for the other one. This positive interspecific interaction is called facilitation.

In a companion article (Carof et al., 2007), we have studied the effects of eight combinations of soil tillage and living mulch management systems on wheat grain yield and its components. Six no-till/living mulch management systems were compared to a no-till system without a living mulch and a conventionally-tilled one. Results showed that undersowing wheat with a living mulch reduced grain yield in fourteen out of the eighteen situations, i.e. in three experiments times six no-till/living mulch management systems, depending on the living mulch species and on the herbicidal management. Furthermore, yield component analysis showed that the stem elongation and/or the flowering and fecundation periods were sensitive ones for eleven out of the eighteen situations. Based on those experiments, the present paper examines competition for light and nitrogen between wheat and living mulch. As only wheat production is profitable, only competitive effects of living mulch on wheat were observed. Furthermore, as the grain filling period is not a sensitive one in the no-till/living mulch management systems (Carof et al., 2007), this article focuses on the competition evidenced from seeding to the beginning of grain filling. 


\section{MATERIALS AND METHODS}

\subsection{Site description}

A field trial was carried out from 2002 through 2005 at the INRA experimental station of Grignon, France $\left(48.9^{\circ} \mathrm{N}\right.$, $1.9^{\circ} \mathrm{E}, 130 \mathrm{~m}$ elevation, $606 \mathrm{~mm}$ annual 30 -year average rainfall). The soil type is an Orthic Luvisol (FAO-UNESCO, 1974) with $250 \mathrm{~g} \mathrm{~kg}^{-1}$ clay, $500 \mathrm{~g} \mathrm{~kg}^{-1}$ silt, and $250 \mathrm{~g} \mathrm{~kg}^{-1}$ sand in the topsoil (total $\mathrm{CaCO}_{3}: 21 \% ; \mathrm{pHH}_{2} \mathrm{O}: 8.2$ ). Due to the presence of a calcareous hardpan, maximal root depth ranged from 0.4 to $0.6 \mathrm{~m}$. Prior to this trial, the site had been conventionally cultivated for several years with annual ploughing. The whole area was ploughed one last time in November 2001.

\subsection{Experimental design and management practices}

As thoroughly described elsewhere (Carof et al., 2007), three wheat (cultivar Isengrain) growing seasons were labelled experiments 1,2, and 3. They were conducted from October 21, 2002 to July 17, 2003, from October 29, 2003 to July 26, 2004, and from October 18, 2004 to July 14, 2005, respectively. Each experiment involved eight combinations of soil tillage and living mulch managements held to from November 2001: a conventionally-tilled management and seven variations on a no-till one. Conventionally-tilled management consisted of an autumnal mouldboard ploughing to a $25-\mathrm{cm}$ depth, followed by two rotary harrowings to a $10-\mathrm{cm}$ depth for final seedbed preparation. The no-till management variations included a no-till treatment without a living mulch and six no-till treatments with a living mulch. The six living mulch species were broadcasted on March 28, 2002 and are as follows: sheep's fescue (Festuca ovina L.), red fescue (Festuca rubra L.), bird's-foot-trefoil (Lotus corniculatus L.), black medic (Medicago lupulina L.), alfalfa (Medicago sativa L.), and white clover (Trifolium repens L.). No-till/living mulch treatments were labelled using initials based on the scientific name of each living mulch species. Each treatment was replicated four times. This experimental design allows us to study (i) effect of soil tillage comparing the conventionally-tilled treatment to the no-till treatment without a living mulch, and (ii) effect of living mulch comparing the no-till/living mulch treatments to the no-till treatment without a living mulch. Management practices were detailed in Carof et al. (2007).

\subsection{Data collection and calculation}

\subsubsection{Canopy structure descriptors}

In experiment 1 , canopy structure descriptors, i.e. height and leaf area of wheat and living mulch, were not measured. In experiment 2, their measurements took place at 190 and 210 days after sowing, and in experiment 3 , they took place at 162, 196 and 217 days after sowing. Wheat and living mulch height were measured on four plants in four plots for the no-till treatment without a living mulch and the no-till treatments with alfalfa, bird's-foot trefoil, and red fescue as a living mulch. Wheat and living mulch height for the no-till treatment with alfalfa as a living mulch was not measured in experiment 2. Wheat and living mulch leaf area were determined by sampling (i) one subplot $0.25 \mathrm{~m}^{2}$ in three plots for the no-till treatment without a living mulch, and the no-till treatments with bird's-foot-trefoil and red fescue as a living mulch in experiment 2 and (ii) two subplots $0.25 \mathrm{~m}^{2}$ in two plots for the notill treatment without a living mulch, and the no-till treatments with alfalfa, bird's-foot-trefoil and red fescue as a living mulch in experiment 3. As mixed species created a multispecies multilayer canopy, two layers were defined for the no-till/living mulch treatments: the top canopy layer (layer 1) only included the upper part of the wheat canopy whereas the bottom canopy layer (layer 2) included the lower part of the wheat canopy as well as the living mulch canopy. Only layer 1 was defined for the no-till treatment without a living mulch. In each layer, a sample of the subplot plant matter was used to measure either leaf area of wheat with an optical planimeter (Delta-T Devices Ltd, Cambridge, United Kingdom) or leaf area of living mulch with an image analysis software (Abramoff et al., 2004: ImageJ) on scanned leaf material. After leaf area measurement, the subplot plant matter of each layer as well as the sample of the subplot plant matter were oven-dried for two days at $80^{\circ} \mathrm{C}$ and weighed. In each layer, leaf area index $\left(\mathrm{m}^{2} \mathrm{~m}^{-2}\right)$ of each mixed species was calculated from the specific leaf area, the specific sample biomass, and the specific subplot biomass.

\subsubsection{Radiative balance}

Radiative balance was determined (i) in experiment 2, in one plot for the no-till treatment without a living mulch, and the no-till treatments with bird's-foot-trefoil and red fescue as a living mulch, and (ii) in experiment 3 , in one plot for the no-till treatment without a living mulch, and the no-till treatments with alfalfa, bird's-foot-trefoil and red fescue as a living mulch. Whatever the experiment, measurements began after the end of tillering. Incident photosynthetically active radiation (PARi; $\mu$ mol m $\mathrm{m}^{-2} \mathrm{~s}^{-1}$ ) was measured above the whole canopy with two replicates of amorphous silicon cells (Solems, Palaiseau, France) for the whole site. The amount of photosynthetically active radiation transmitted to the soil (PARt) was measured with two amorphous silicon cells per plot, placed on the ground between two wheat rows. The amount of photosynthetically active radiation reflected by the whole canopy (PARr) was measured with two amorphous silicon cells per plot, faced down the whole canopy. For the no-till/living mulch treatments, the amount of photosynthetically active radiation transmitted to the bottom of layer 1 (PARt1) was measured with two amorphous silicon cells per plot, placed at the top of layer 2 between two wheat rows. Cells were regularly moved according to living mulch height. Data of individual sensors were scanned every ten minutes, averaged every one hour, and collected on a Campbell CR10X data logger (Campbell Scientific Inc., Shepshed, UK). Daily integration of both incident, transmitted, and reflected 
photosynthetically active radiation was used to compute daily interception efficiency of photosynthetically active radiation by the whole canopy ( $\varepsilon_{d}$; unitless):

$$
\varepsilon_{\mathrm{d}}=\frac{\sum_{\mathrm{h}=1}^{24}\left(\mathrm{PARi}_{\mathrm{h}}-\mathrm{PARt}_{\mathrm{h}}-\mathrm{PARr}_{\mathrm{h}}\right)}{\sum_{\mathrm{h}=1}^{24} \mathrm{PARi}_{\mathrm{h}}}
$$

where $d$, in day after sowing, is the date of a photosynthetically active radiation measurement; $h$, in hour, is the time of a photosynthetically active radiation measurement during day $\mathrm{d}$.

Daily interception efficiency of photosynthetically active radiation by wheat ( $\varepsilon_{\text {wheat } d}$; unitless) for the no-till treatment without a living mulch was daily interception efficiency of photosynthetically active radiation by the whole canopy. Daily interception efficiency of photosynthetically active radiation by wheat for the no-till/living mulch treatments was defined as follows:

$$
\begin{gathered}
\varepsilon_{\text {wheat } \mathrm{d}}=\frac{\sum_{\mathrm{h}=1}^{24}\left(\mathrm{PARi}_{\mathrm{h}}-\mathrm{PARt}_{\mathrm{h}}-\mathrm{PARr}_{\mathrm{h}}\right)}{\sum_{\mathrm{h}=1}^{24} \mathrm{PARi}_{\mathrm{h}}} \\
+\mathrm{X}_{\text {wheat } \mathrm{d}} \frac{\sum_{\mathrm{h}=1}^{24}\left(\mathrm{PARt}_{\mathrm{h}}-\mathrm{PARt}_{\mathrm{h}}\right)}{\sum_{\mathrm{h}=1}^{24} \mathrm{PARi}_{\mathrm{h}}}
\end{gathered}
$$

where $\mathrm{x}_{\text {wheat } \mathrm{d}}$, unitless, is the fraction of incident photosynthetically active radiation at the top of layer 2 intercepted by the wheat in this canopy layer during day $\mathrm{d}$.

Daily interception efficiency of photosynthetically active radiation by living mulch ( $\varepsilon_{\text {cover crop d }}$; unitless) was defined as follows:

$$
\varepsilon_{\text {cover crop d }}=\left(1-\mathrm{X}_{\text {wheat d }}\right) \frac{\sum_{\mathrm{h}=1}^{24}\left(\mathrm{PARt}_{\mathrm{h}}-\mathrm{PARt}_{\mathrm{h}}\right)}{\sum_{\mathrm{h}=1}^{24} \mathrm{PARi}_{\mathrm{h}}} .
$$

To determine $\mathrm{x}_{\text {wheat } \mathrm{d}}$, we used the Kubelka-Munk equations derived by Sinoquet et al. (2000). In a multispecies multilayer canopy, these equations allowed for the determination of radiation partitioning between each component of each canopy layer. $x_{\text {wheat } d}$ was the ratio of wheat radiation interception efficiency in layer 2 to radiation interception efficiency for all components in layer 2. Main parameters were leaf inclination of each species of the canopy $\left(45^{\circ}\right.$ for wheat, $63^{\circ}$ for grass, and $27^{\circ}$ for leguminous), leaf scattering coefficient of each component of the canopy ( 0.20 whatever the component), and soil reflectance (0.15). The input variable was leaf area index of each component of each layer. Daily estimates of $\mathrm{x}_{\text {wheat } \mathrm{d}}$ between measuring days were interpolated by linear regression. After the last measuring day, $\mathrm{x}_{\text {wheat } \mathrm{d}}$ was considered to be constant.

\subsubsection{Crop above-ground biomass and nitrogen uptake, wheat nitrogen status}

Plant measurements were carried out at the end of tillering and at flowering. In experiment 1 , for technical reasons, the second plant measurement took place fifteen days after flowering. Whatever the sampling date, above-ground biomass as well as total nitrogen concentration of wheat and living mulch were determined by sampling two subplots $0.25 \mathrm{~m}^{2}$ per plot. Samples were weighed after oven-drying for two days at $80{ }^{\circ} \mathrm{C}$. Then, samples were ground using a $0.5-\mathrm{mm}$ mesh grid and total nitrogen concentration was measured using the Dumas (1831) method. After averaging subplots for biomass $\left(\mathrm{g} \mathrm{m}^{-2}\right)$ and total nitrogen concentration $\left(\mathrm{g} \mathrm{g}^{-1}\right)$, above-ground nitrogen uptake $\left(\mathrm{g} \mathrm{m}^{-2}\right)$ for wheat and living mulch was calculated as the product of biomass time total nitrogen concentration.

Wheat nitrogen status was characterized using nitrogen nutrition index calculated as the ratio of measured nitrogen concentration of the aerial parts to critical nitrogen concentration $\left(N_{t} ; \%\right)$. The critical nitrogen concentration corresponds to the minimum nitrogen concentration of the aerial parts required to ensure maximal growth. Critical nitrogen concentration for wheat was determined using the following equations (Justes et al., 1997):

$$
\begin{aligned}
& \text { if } \mathrm{DM}<1.55 \mathrm{Mg} \mathrm{ha}^{-1}, N_{t}=4.4 \% \\
& \text { if } \mathrm{DM} \geqslant 1.55 \mathrm{Mg} \mathrm{ha}^{-1}, N_{t}=5.35 \times(\mathrm{DM})^{-0.442}
\end{aligned}
$$

where $\mathrm{DM}$, in $\mathrm{Mg} \mathrm{ha}^{-1}$, is accumulated dry matter in wheat shoots.

If nitrogen nutrition index is equal to or higher than 1 , wheat nitrogen status is not limiting for growth. If nitrogen nutrition index is lower than 0.9, wheat is nitrogen-deficient (Jeuffroy and Bouchard, 1999). The lower the nitrogen nutrition index, the more severe the deficiency is.

\subsection{Statistical analysis}

Data from all the experiments were analysed by means of the general linear model procedure available from SAS/STAT (SAS Institute Inc., 1999). For wheat height, living mulch height was designated as covariate; for leaf area index of wheat in the bottom canopy layer, leaf area index of living mulch was designated as covariate. Experiment, measurement date within an experiment, treatment within an experiment, and block within an experiment were designated as fixed effects. For leaf area index of wheat in the whole canopy, the general linear model procedure was carried out at each measurement date of each experiment. Treatment and block were designated as fixed effects. For above-ground biomass, nitrogen uptake, and nitrogen nutrition index, the general linear model procedure was carried out at each sampling date. Experiment, treatment within an experiment, and block within an experiment were designated as fixed effects. Means were separated by $P$-values $(P \leqslant 0.05)$ associated with least-squares mean (LSMEANS) statement. 
a) Plant height (cm)

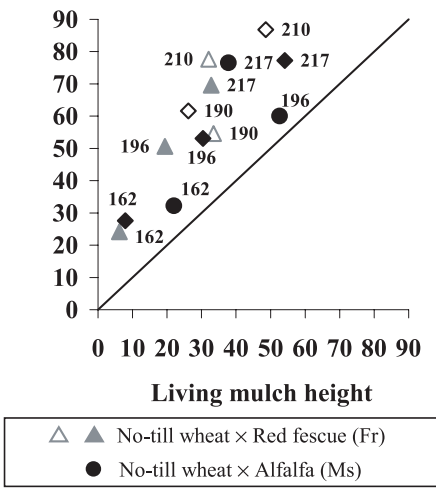

b) Plant leaf area index in the mixed canopy layer (LAI; $\mathrm{m}^{2} \mathrm{~m}^{-2}$ )

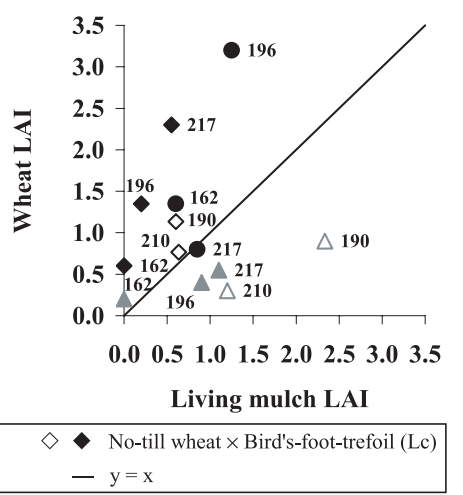

Figure 1. Canopy structure of wheat and living mulch: relationship between wheat height and living mulch height $\left(\mathrm{a} ; \mathrm{R}^{2}=0.98, P \leqslant 0.05\right)$ and relationship between leaf area index of wheat in the mixed canopy layer and leaf area index of living mulch $\left(\mathrm{b} ; \mathrm{R}^{2}=0.62, P \leqslant 0.05\right)$. Open symbols are measurements carried out in experiment 2 (190 and 210 days after sowing). Closed symbols are measurements carried out in experiment 3 (162, 196 and 217 days after sowing).

Table I. Leaf area index of wheat $\left(\mathrm{m}^{2} \mathrm{~m}^{-2}\right)$ in the whole canopy at five sampling dates for four treatments. Within a sampling date, values followed by the same letter are not significantly different (LSMEANS, $P \leqslant 0.05$ ). n.s. means that the general linear model procedure is not significant.

\begin{tabular}{|c|c|c|c|c|c|}
\hline \multirow[b]{3}{*}{ Treatment } & \multicolumn{5}{|c|}{ Experiment and Sampling date (day after sowing) } \\
\hline & \multicolumn{2}{|c|}{ Experiment 2} & \multicolumn{3}{|c|}{ Experiment 3} \\
\hline & 190 & 210 & 162 & 196 & 217 \\
\hline No-till wheat without a living mulch (NT) & $3.3 \mathrm{a}$ & 1.9 n.s. & $2.0 \mathrm{a}$ & $4.7 \mathrm{a}$ & 2.9 n.s. \\
\hline No-till wheat $\times$ Red fescue $(\mathrm{Fr})$ & $1.4 \mathrm{~b}$ & 1.2 n.s. & $0.8 \mathrm{c}$ & $2.5 \mathrm{~b}$ & 2.4 n.s. \\
\hline No-till wheat $\times$ Bird's-foot-trefoil $(\mathrm{Lc})$ & $2.9 \mathrm{a}$ & 1.8 n.s. & $1.3 \mathrm{~b}$ & $3.7 \mathrm{ab}$ & 3.1 n.s. \\
\hline No-till wheat $\times$ Alfalfa $(\mathrm{Ms})$ & - & - & $1.4 \mathrm{~b}$ & $3.6 \mathrm{ab}$ & 3.5 n.s. \\
\hline
\end{tabular}

\section{RESULTS AND DISCUSSION}

Because water shortage could interfere with light and nitrogen competition relationships between mixed species, we determined soil available water reserve from seeding to the beginning of grain filling. We concluded that under the environmental conditions of our experiments, water was not a main limiting factor (data not shown).

\subsection{Canopy structure: height and leaf area index of mixed species}

As spatial variation in canopy structure may affect light interception and partitioning between mixed species (Sinoquet and Caldwell, 1995), descriptors (height, leaf area index) of canopy structure were measured for some treatments in the top canopy layer as well as in the bottom canopy layer, i.e. the mixed one. Whatever the experiment, the sampling date, and the no-till/living mulch treatment, wheat was taller than living mulch (Fig. 1a). However, wheat undersown with red fescue was shorter than wheat undersown with alfalfa or bird's-foottrefoil, excepted for wheat $\times$ bird's-foot-trefoil in experiment 3 where wheat height was similar to that for wheat $\times$ red fescue.
In the mixed canopy layer for wheat $\times$ red fescue, leaf area index of wheat was lower than leaf area index of living mulch in four out of the five sampling dates, contrary to the other no-till/living mulch treatments (Fig. 1b). Furthermore, compared to alfalfa and bird's-foot-trefoil, presence of red fescue reduced leaf area index of wheat in the mixed canopy layer; this was significant for experiment 3 (LSMEANS, $P \leqslant 0.05$ ). In the whole canopy, regardless the experiment, leaf area index of wheat undersown with red fescue was always lower than leaf area index of wheat cropped alone on a no-till soil (Tab. I). This effect was also noticed when wheat $\times$ red fescue was compared to wheat $\times$ alfalfa and wheat $\times$ bird's-foottrefoil but it was only significant for one (wheat $\times$ alfalfa) or two (wheat $\times$ bird's-foot-trefoil) sampling dates. Finally, living mulches presented contrasted canopy structures, from short living mulch canopy with high leaf area index (e.g. red fescue at 190 days after sowing in experiment 2) to high living mulch canopy with low leaf area index (e.g. bird's-foot-trefoil at 217 days after sowing in experiment 3 ).

As far as height was concerned, our results showed wheat always dominated living mulch. However, in the mixed canopy layer, wheat foliage may have been dominated by living mulch foliage, depending on the living mulch species: this was true for red fescue. Furthermore, our results highlighted the fact 
Photosynthetically active radiation intercepted by wheat and living mulch (PAR; \%)

No-till wheat without a living mulch (NT)

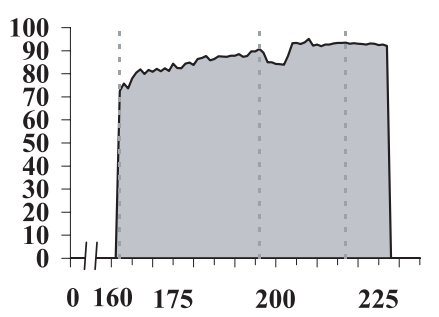

No-till wheat $\times$ Bird's-foot-trefoil (Lc)

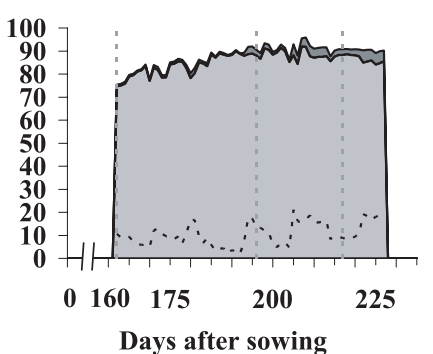

No-till wheat $\times$ Red fescue $(\mathrm{Fr})$

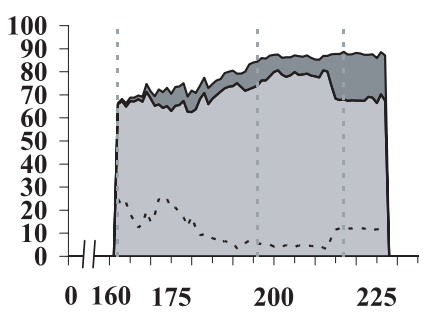

No-till wheat $\times$ Alfalfa (Ms)

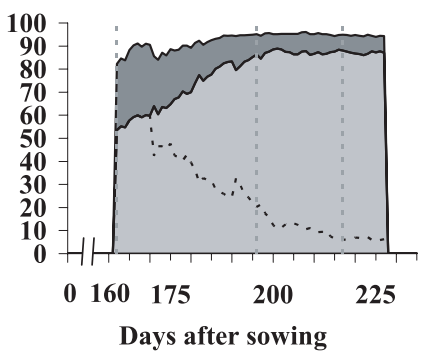

- PAR intercepted by wheat in the whole canopy

.... PAR intercepted by wheat in the mixed canopy layer

PAR intercepted by living mulch

Figure 2. Daily photosynthetically active radiation intercepted by wheat and living mulch for experiment 3 . Vertical dashed lines indicate sampling dates of leaf area index.

that this living mulch reduced leaf area index of wheat in the whole canopy. As a consequence, undersowing wheat with red fescue changed wheat canopy structure compared to that for the other no-till treatments, especially the one without a living mulch. Other authors reported foliage dominance of wheat by another species as well as changes in canopy structure between mixed and sole crops. For example, Hashem et al. (1998) noticed that at 200 days after emergence, leaf area index of Italian ryegrass (Lolium multiflorum Lam.), mixed with wheat, was up to 6.6 times greater than that of wheat. Eslami et al. (2006) showed presence of a weed, wild radish (Raphanus raphanistrum L.), reduced leaf area index of wheat compared to sole crop. Variation of wheat leaf area index between mixed and sole crops may be due to fast foliage growth of sole crops as it was observed for Arachis pintoi in a Digitaria decumbens/A. pintoi interspecies-crop management system compared to sole crops (Sinoquet and Cruz, 1993). Moreover, changes in canopy structure between mixed and sole crops may be a consequence of species ability to occupy restricted space (Tremmel and Bazzaz, 1995). Space competitive ability may be related to plant emergence kinetics: the plant that emerges first in the field acquires the competitive advantage (Wallace et al., 1991; Bond and Grundy, 2001). According to Cousens et al. (2003), the key point is plant aboveground biomass rather than date of plant emergence: the plant that achieves the greater biomass early on remains the better competitor throughout the growth. In experiment 2, red fescue gained this competitive advantage as its biomass at the end of tillering was 2 times higher than wheat biomass $\left(115.19 \mathrm{~g} \mathrm{~m}^{-2}\right.$ vs. $57.60 \mathrm{~g} \mathrm{~m}^{-2}$ ); just the opposite, biomass of bird's-foottrefoil was 13.5 times lower than wheat biomass $\left(7.23 \mathrm{~g} \mathrm{~m}^{-2}\right.$ vs. $98.02 \mathrm{~g} \mathrm{~m}^{-2}$ ). In experiment 3 , decrease in leaf area index of wheat undersown with red fescue resulted from high incidence of wheat bulb fly (Delia coarctata Fallen) which reduced plant number per $\mathrm{m}^{2}$ (Carof et al., 2007).

\subsection{Interception and partitioning of photosynthetically active radiation between mixed species}

Figure 2 illustrated for experiment 3, changes in the daily amount of photosynthetically active radiation intercepted by (i) wheat in the whole canopy, (ii) wheat in the mixed canopy layer, and (iii) living mulch in the mixed canopy layer. Table II gives the cumulative amount of photosynthetically active radiation intercepted by wheat and living mulch during the measurement periods of experiments 2 and 3 . We can thus observe partitioning of photosynthetically active radiation between mixed species and compare interception efficiency of photosynthetically active radiation for wheat sole crop and that for wheat mixed with another plant species. Measurements of photosynthetically active radiation showed competition for light occurred between mixed species as the amount of photosynthetically active radiation intercepted by wheat for the no-till/living mulch treatments was lower than that for the no-till treatment without a living mulch (Tab. II). 
Table II. Means and standard deviations of cumulative photosynthetically active radiation $\left(\mathrm{mmol} \mathrm{m}^{-2} \mathrm{~s}^{-1}\right)$ intercepted by wheat in the mixed canopy layer $\left(\mathrm{PAR}_{2}\right)$, wheat in the whole canopy $\left(\mathrm{PAR}_{0}\right)$ and living mulch in the mixed canopy layer $\left(\mathrm{PAR}_{2}\right)$ from 191 days after sowing to 220 days after sowing for three treatments for experiment 2, and from 162 days after sowing to 227 days after sowing for four treatments for experiment 3 .

\begin{tabular}{lllll}
\hline & & \multicolumn{2}{l}{ Plant } & \\
\cline { 3 - 5 } Experiment & & Wheat & \multicolumn{2}{l}{ Living mulch } \\
& Treatment & PAR $_{2}$ & PAR $_{0}$ & PAR $_{2}$ \\
\hline 2 & No-till wheat without a living mulch (NT) & - & $242 \pm 4$ & - \\
& No-till wheat $\times$ Red fescue (Fr) & $29 \pm 1$ & $166 \pm 2$ & $86 \pm 3$ \\
& No-till wheat $\times$ Bird's-foot-trefoil (Lc) & $35 \pm 4$ & $221 \pm 3$ & $28 \pm 4$ \\
3 & No-till wheat without a living mulch (NT) & - & $421 \pm 6$ & - \\
& No-till wheat $\times$ Red fescue (Fr) & $49 \pm 16$ & $339 \pm 43$ & $49 \pm 12$ \\
& No-till wheat $\times$ Bird's-foot-trefoil (Lc) & $47 \pm 6$ & $374 \pm 23$ & $10 \pm 1$ \\
& No-till wheat $\times$ Alfalfa (Ms) & $108 \pm 16$ & $380 \pm 39$ & $64 \pm 5$ \\
\hline
\end{tabular}

However, major differences existed between treatments. Red fescue competed the most vigorously for light with wheat when compared to the other living mulches as the cumulative amount of photosynthetically active radiation intercepted by wheat in wheat $\times$ red fescue was the lowest. Competition for light between wheat and the leguminous living mulches was less severe. Nevertheless, competitive ability of alfalfa was high at the beginning of the measurement period and decreased over the course of time (Fig. 2) due to the herbicide use. Finally, as the cumulative amount of photosynthetically active radiation intercepted by wheat was higher than the cumulative amount of photosynthetically active radiation intercepted by living mulch (Tab. II), it confirmed wheat canopy dominance previously observed according to the height descriptor (Fig. 1).

The different patterns of living mulch canopy structure (Fig. 1) enhanced competitive ability of the different living mulch species to intercept radiation (Fig. 2). Competitive ability of a species is related to its shading ability (Wallace et al., 1991). Blackshaw (1994) showed weed grass (Bromus tectorum L.) reduced biomass of four wheat cultivars differently according to cultivar traits. He found that those which were shaded by $B$. tectorum for much of the growing season presented the lowest biomass. Olesen et al. (2004) simulated competition for light, nitrogen, and water between different wheat cultivars and a sown grass mixture. They demonstrated competitive ability of wheat was related to three major traits: early crop development, rapid height growth, and specific leaf area. This was also observed by Seavers and Wright (1999). Vertical distribution of leaf area and leaf area contribution of each species also affects competitive ability of a species (Sinoquet and Cruz, 1993; Lantinga et al., 1999; Dong et al., 2005). What our results did show was that competitive ability of wheat undersown with a living mulch was the highest, when most of wheat foliage was in the top canopy layer, i.e. when wheat was much taller than living mulch, and when leaf area of wheat in the mixed canopy layer was greater than that of living mulch.

\subsection{Above-ground biomass and nitrogen nutrition index: indicators of competition for light and nitrogen}

Competition for soil nitrogen may occur for wheat undersown with a living mulch. In order to highlight worse or better wheat nitrogen nutrition in interspecies-crop systems, nitrogen status of wheat in the mixed crops was compared to nitrogen status of wheat in the sole crop, using nitrogen nutrition index (Tab. III). At the same time, wheat aboveground biomass in the mixed crops was compared to wheat above-ground biomass in the sole crop. According to Cruz and Soussana (1997), this approach allows us to separate competitive relationships for light and nitrogen between mixed species. If wheat nitrogen deficiency occurs (i.e. nitrogen nutrition index was lower than 0.90) in the treatments without a living mulch, it gave rise to processes that reduce nitrogen availability to wheat, independently of competition between mixed species. At the end of tillering, wheat nitrogen deficiency for the conventionally-tilled treatment occurred in experiments 1 and 2 whereas that for the no-till treatment without a living mulch only occurred in experiment 1 (Tab. III). At flowering, wheat nitrogen deficiency occurred in the two treatments without a living mulch, whatever the experiment. Our results showed variation of wheat nitrogen status between the conventionally-tilled treatment and the no-till treatment without a living mulch only occurred at the beginning of wheat growth cycle. At flowering, whatever the experiment, neither wheat nitrogen status, nor wheat above-ground biomass differed between treatments without a living mulch. Furthermore, in the companion article (Carof et al., 2007), we demonstrated that the treatments without a living mulch resulted in similar yield. As a consequence, under our environmental conditions, soil tillage had no effect on nitrogen dynamics. However, this finding cannot be applied generally to no-till systems in equilibrium as our no-till treatment without a living mulch was in the transition period from mouldboard ploughing to notill. Insufficient time without ploughing had elapsed for soil structural change that could have disturbed crop environmental conditions (Kinsella, 1995). 
Table III. Effect of soil tillage and living mulch on wheat above-ground biomass (Biomass; $\mathrm{Mg} \mathrm{ha}^{-1}$ ), wheat nitrogen nutrition index (NNI; unitless) and wheat and living mulch nitrogen uptake ( $\mathrm{N}$ uptake; $\mathrm{kg} \mathrm{ha}^{-1}$ ) at two sampling dates for three experiments. Treatments are: conventionally-tilled wheat (CT); no-till wheat $\times$ sheep's fescue (Fo), red fescue (Fr), bird's-foot-trefoil (Lc), black medic (Ml), alfalfa (Ms) and white clover (Tr). For each experiment, means followed by the same letter within a column are not significantly different (LSMEANS, $P \leqslant 0.05)$.

\begin{tabular}{|c|c|c|c|c|c|c|c|c|}
\hline \multirow[b]{2}{*}{ Treatment } & \multicolumn{4}{|c|}{ End of tillering } & \multicolumn{4}{|l|}{ Flowering } \\
\hline & $\begin{array}{l}\text { Wheat } \\
\text { Biomass }\end{array}$ & NNI & $\mathrm{N}$ uptake & $\begin{array}{l}\text { Living mulch } \\
\mathrm{N} \text { uptake }\end{array}$ & $\begin{array}{l}\text { Wheat } \\
\text { Biomass }\end{array}$ & NNI & $\mathrm{N}$ uptake & $\begin{array}{l}\text { Living mulch } \\
\mathrm{N} \text { uptake }\end{array}$ \\
\hline \multicolumn{9}{|c|}{ Experiment 1} \\
\hline CT & $0.507 \mathrm{a}$ & $0.60 \mathrm{c}$ & $13.3 \mathrm{abc}$ & - & $8.860 \mathrm{a}$ & $0.71 \mathrm{a}$ & $128.2 \mathrm{a}$ & - \\
\hline NT & $0.445 \mathrm{a}$ & $0.64 \mathrm{bc}$ & $12.6 \mathrm{abc}$ & - & $9.143 \mathrm{a}$ & $0.74 \mathrm{a}$ & $136.3 \mathrm{a}$ & - \\
\hline Fo & $0.150 \mathrm{~b}$ & $0.56 \mathrm{c}$ & $3.7 \mathrm{~cd}$ & $21.8 \mathrm{bc}$ & $3.384 \mathrm{bc}$ & $0.43 \mathrm{bc}$ & $46.9 \mathrm{bc}$ & $65.7 \mathrm{c}$ \\
\hline $\mathrm{Fr}$ & $0.111 \mathrm{~b}$ & $0.56 \mathrm{c}$ & $2.7 \mathrm{~d}$ & $20.6 \mathrm{c}$ & $1.426 \mathrm{c}$ & $0.31 \mathrm{c}$ & $19.1 \mathrm{c}$ & $88.2 \mathrm{bc}$ \\
\hline Lc & $0.479 \mathrm{a}$ & $0.79 \mathrm{a}$ & $16.4 \mathrm{ab}$ & $27.8 \mathrm{bc}$ & $5.260 \mathrm{~b}$ & $0.50 \mathrm{~b}$ & $70.3 \mathrm{~b}$ & $94.6 \mathrm{bc}$ \\
\hline Ml & $0.579 \mathrm{a}$ & $0.74 \mathrm{ab}$ & $18.6 \mathrm{a}$ & $41.0 \mathrm{~b}$ & $5.138 \mathrm{~b}$ & $0.52 \mathrm{~b}$ & $70.2 \mathrm{~b}$ & $93.1 \mathrm{bc}$ \\
\hline Ms & $0.377 \mathrm{ab}$ & $0.77 \mathrm{a}$ & $12.8 \mathrm{abc}$ & $69.0 \mathrm{a}$ & $1.578 \mathrm{c}$ & $0.39 \mathrm{bc}$ & $23.0 \mathrm{c}$ & $144.0 \mathrm{a}$ \\
\hline $\operatorname{Tr}$ & $0.297 \mathrm{ab}$ & $0.73 \mathrm{ab}$ & $9.1 \mathrm{bcd}$ & $80.9 \mathrm{a}$ & $3.833 \mathrm{bc}$ & $0.45 \mathrm{bc}$ & $50.7 \mathrm{bc}$ & \\
\hline \multicolumn{9}{|c|}{ Experiment 2} \\
\hline $\mathrm{CT}$ & $0.917 \mathrm{a}$ & $0.78 \mathrm{c}$ & $31.5 \mathrm{ab}$ & - & $10.784 \mathrm{a}$ & $0.64 \mathrm{ab}$ & $129.1 \mathrm{a}$ & - \\
\hline NT & $0.737 \mathrm{ab}$ & $0.94 \mathrm{a}$ & $30.4 \mathrm{~b}$ & - & $10.365 \mathrm{a}$ & $0.63 a b c$ & $125.9 \mathrm{a}$ & - \\
\hline Fo & $0.593 \mathrm{bc}$ & $1.01 \mathrm{a}$ & $26.3 \mathrm{~b}$ & $37.9 \mathrm{~b}$ & $7.222 \mathrm{bc}$ & $0.56 \mathrm{bcd}$ & $91.2 \mathrm{ab}$ & $77.1 \mathrm{~b}$ \\
\hline $\mathrm{Fr}$ & $0.576 \mathrm{bc}$ & $0.97 \mathrm{a}$ & $25.0 \mathrm{~b}$ & $33.5 \mathrm{~b}$ & $6.569 \mathrm{bc}$ & $0.50 \mathrm{bcd}$ & $77.5 \mathrm{bc}$ & $79.7 \mathrm{ab}$ \\
\hline Lc & $0.980 \mathrm{a}$ & $0.92 \mathrm{a}$ & $39.7 \mathrm{a}$ & $2.9 \mathrm{c}$ & $8.866 \mathrm{ab}$ & $0.71 \mathrm{a}$ & $129.3 \mathrm{a}$ & $25.0 \mathrm{c}$ \\
\hline Ml & $0.362 \mathrm{~cd}$ & $0.80 \mathrm{bc}$ & $12.7 \mathrm{c}$ & $26.0 \mathrm{~b}$ & $3.877 \mathrm{~d}$ & $0.49 \mathrm{~cd}$ & $55.9 \mathrm{bc}$ & $53.9 \mathrm{bc}$ \\
\hline Ms & $0.615 \mathrm{bc}$ & $0.90 \mathrm{ab}$ & $24.6 \mathrm{~b}$ & $91.3 \mathrm{a}$ & $4.594 \mathrm{~cd}$ & $0.62 \mathrm{abc}$ & $77.3 \mathrm{bc}$ & $122.3 \mathrm{a}$ \\
\hline $\operatorname{Tr}$ & $0.315 \mathrm{~d}$ & $0.81 \mathrm{bc}$ & $10.8 \mathrm{c}$ & $24.0 \mathrm{~b}$ & $3.551 \mathrm{~d}$ & $0.46 \mathrm{~d}$ & $51.1 \mathrm{c}$ & $63.7 \mathrm{bc}$ \\
\hline \multicolumn{9}{|c|}{ Experiment 3} \\
\hline $\mathrm{CT}$ & $1.495 \mathrm{a}$ & $0.93 \mathrm{~b}$ & $59.5 \mathrm{a}$ & - & $12.825 \mathrm{a}$ & $0.75 a b c$ & $166.1 \mathrm{a}$ & - \\
\hline NT & $1.111 \mathrm{~b}$ & $0.98 \mathrm{ab}$ & $47.7 \mathrm{~b}$ & - & $11.649 \mathrm{ab}$ & $0.62 \mathrm{c}$ & $131.4 \mathrm{abc}$ & - \\
\hline Fo & $0.559 \mathrm{e}$ & $1.07 \mathrm{a}$ & $24.6 \mathrm{~d}$ & $14.2 \mathrm{~b}$ & $6.121 \mathrm{de}$ & $0.70 \mathrm{bc}$ & $101.9 \mathrm{c}$ & $24.0 \mathrm{ab}$ \\
\hline $\mathrm{Fr}$ & $0.510 \mathrm{e}$ & $1.02 \mathrm{ab}$ & $21.6 \mathrm{~d}$ & $1.7 \mathrm{~b}$ & $6.105 \mathrm{de}$ & $0.65 \mathrm{c}$ & $94.1 \mathrm{c}$ & $36.1 \mathrm{ab}$ \\
\hline $\mathrm{Lc}$ & $0.855 \mathrm{~cd}$ & $1.09 \mathrm{a}$ & $40.9 \mathrm{bc}$ & $6.3 \mathrm{~b}$ & $8.845 \mathrm{~cd}$ & $0.82 \mathrm{ab}$ & $147.7 \mathrm{ab}$ & $15.7 \mathrm{ab}$ \\
\hline Ml & $1.050 \mathrm{bc}$ & $1.03 \mathrm{ab}$ & $47.1 \mathrm{~b}$ & $7.3 \mathrm{~b}$ & $8.765 \mathrm{~cd}$ & $0.84 \mathrm{a}$ & $152.0 \mathrm{a}$ & $0.0 \mathrm{~b}$ \\
\hline Ms & $0.936 \mathrm{bcd}$ & $1.02 \mathrm{ab}$ & $41.7 \mathrm{bc}$ & $40.9 \mathrm{a}$ & $8.994 \mathrm{bc}$ & $0.86 \mathrm{a}$ & $158.2 \mathrm{a}$ & $50.9 \mathrm{a}$ \\
\hline $\operatorname{Tr}$ & $0.755 \mathrm{de}$ & $1.05 \mathrm{a}$ & $34.4 \mathrm{c}$ & $17.0 \mathrm{~b}$ & $5.786 \mathrm{e}$ & $0.79 \mathrm{ab}$ & $113.0 \mathrm{bc}$ & $1.7 \mathrm{~b}$ \\
\hline
\end{tabular}

At the end of tillering, competition for nitrogen occurred in two out of the eighteen interspecies-crop situations (i.e. in three experiments times six no-till/living mulch treatments): in experiment 2 , wheat nitrogen nutrition index for wheat $\times$ black medic and wheat $x$ white clover was significantly lower than that for the no-till treatment without a living mulch. Furthermore, this competition for nitrogen was accompanied by competition for light as wheat above-ground biomass for wheat $x$ black medic and wheat $x$ white clover was significantly lower than that for the no-till treatment without a living mulch. As far as wheat above-ground biomass was concerned, that for wheat $\times$ red fescue and wheat $\times$ sheep's fescue was significantly lower than that for the no-till treatment without a living mulch in two out of the three experiments. In experiment 1, biomass variation between the grass treatments and the no-till treatment without a living mulch resulted from competition for light whereas in experiment 3 , it also resulted from high incidence of wheat bulb fly which reduced plant number per $\mathrm{m}^{2}$ for the grass treatments, as previously said. At the end of tillering, competition for light also occurred for wheat $\times$ bird's-foottrefoil and wheat $\times$ white clover in experiment 3 . At flowering of experiment 1 , competition for nitrogen occurred in all the no-till/living mulch treatments, even when living mulch was a leguminous one. In the other experiments, competition for nitrogen was only observed in wheat $x$ white clover in experiment 2. However, as low nitrogen nutrition index for wheat $\times$ black medic was close to that for wheat $x$ white clover in this experiment, we assumed competition for nitrogen also occurred for wheat $\times$ black medic. We noticed that wheat and living mulch nitrogen uptake was always lower than the amount of fertiliser nitrogen applied. Finally, competition for light was observed in sixteen out of the eighteen interspecies-crop situations.

In experiment 1 , whatever the sampling date, wheat nitrogen deficiency may have resulted from a defective nitrogen uptake since that for the treatments without a living mulch was particularly low when compared to the amount of fertiliser nitrogen applied. Two factors may explain why nitrogen 
was inadequately available for wheat. First, fertiliser pellets did not dissolve into the soil as the fertiliser nitrogen applications were carried out during periods with very low rainfall. Secondly, nitrogen may have been lost for wheat through ammonia volatilisation of $\mathrm{NH}_{4} \mathrm{NO}_{3}$ fertiliser as environmental conditions of our study may have promoted this phenomenon: dry weather, alkaline and calcareous soil (Recous et al., 1992). At flowering in experiments 2 and 3 , wheat nitrogen deficiency may have been temporary, due to the short delay between third fertiliser nitrogen application and sampling date. Under the given environmental conditions of our experiments (i.e. high rates of fertilisation), living mulches rarely competed for nitrogen with wheat. Either soil nitrogen resource was not limiting or mixed species explored different volumes of air and soil or different ecological niches for nitrogen uptake (Vandermeer, 1989; Jumpponen et al., 2002; Ghaley et al., 2005). A better understanding of nitrogen partitioning between mixed species by using ${ }^{15} \mathrm{~N}$ enrichment techniques should be sought (Hauggaard-Nielsen et al., 2001). In our interspeciescrop systems, competition for light between wheat and living mulch was much more frequent than competition for nitrogen, especially at flowering. This result is in agreement with that of Cruz and Sinoquet (1994) for a D. decumbens/A. pintoi interspecies-crop system. Moreover, most of the time, competition for light was not accompanied by competition for nitrogen, i.e. competition for light did not result from competition for nitrogen, which may reduce wheat radiation-use efficiency and/or leaf area index of wheat (Justes et al., 1997). Thus, in our study, interception of photosynthetic active radiation and its partitioning between mixed species was the main reason of competition for light, as previously observed. As this competition mainly affected two yield components (spike per tiller and grains per spike), it mainly occurred during the stem elongation period as well as the flowering and fecundation ones (Carof et al., 2007). From experiment to experiment, improvement of herbicidal management applied during these periods allowed us to better control living mulch growth. Consequently, it allowed us to reduce light competitive effect of living mulch on wheat. For example, in experiment 3 , competitive ability of alfalfa decreased over the course of time due to the herbicide use (Fig. 2): as a result, grain yield of wheat $x$ alfalfa was similar to that of the no-till treatment without a living mulch (see Fig. 1 in Carof et al., 2007).

\section{CONCLUSION}

Our results revealed that competition for nitrogen was not notable when wheat was mixed with a living mulch as fertiliser nitrogen supply, calculated thanks to wheat and living mulch nitrogen requirements, prevents this competition. Furthermore, in the long-term use of no-till/living mulch systems, we assume that recycling of nitrogen-rich leguminous living mulch residues could lead to a substantial decrease of fertiliser nitrogen use. Our study showed that wheat and living mulch mainly competed for light resource due to light partitioning between mixed species. This competition may be managed through the spatial structure of the living mulch, directly through choice of living mulch species (height, leaf area index) and cutting of the living mulch (or herbicide use) during the growing season. One challenge is to manage canopy structure of living mulch in order to enhance its capacity to control weeds by covering up weeds during the off-growing season while avoiding light competition with wheat during cash crop growth cycle.

Acknowledgements: We would like to thank G. Grandeau for his technical assistance with the field trial. We are grateful to F. Lafouge, R. Gosse, and C. Souin for their help with the measurements. We are also grateful to T. Doré for his comments on the preparation of this article. We thank S. Tanis-Plant for her editorial work in English.

\section{REFERENCES}

Abramoff M.D., Magelhaes P.J., Ram S.J. (2004) Image Processing with ImageJ, Biophotonics Int. 11, 36-42.

Basic F., Kisic I., Mesic M., Nestroy O., Butorac A. (2004) Tillage and crop management effects on soil erosion in central Croatia, Soil Till. Res. 78, 197-206.

Blackshaw R.E. (1994) Differential competitive ability of winter wheat cultivars against downy brome, Agron. J. 86, 649-654.

Bond W., Grundy A.C. (2001) Non-chemical weed management in organic farming systems, Weed Res. 41, 383-405.

Carof M., de Tourdonnet S., Saulas P., Le Floch D., Roger-Estrade J. (2007) Undersowing wheat with different living mulches in a notill system. I. Yield analysis, Agron. Sustain. Dev. 27, 347-356.

Cousens R.D., Barnett A.G., Barry G.C. (2003) Dynamics of competition between wheat and oat: I. Effects of changing the timing of phenological events, Agron. J. 95, 1295-1304.

Cruz P., Soussana J.F. (1997) Mixed crops, in: Lemaire G. (Ed.), Diagnosis of the nitrogen status in crops, Springer-Verlag, Berlin Heidelberg, pp. 131-144.

Cruz P.A., Sinoquet H. (1994) Competition for light and nitrogen during a regrowth cycle in a tropical forage mixture, Field Crop. Res. 36, 21-30.

Dong S.K., Long R.J., Hu Z.Z., Kang M.Y. (2005) Productivity and persistence of perennial grass mixtures under competition from annual weeds in the alpine region of the Qinghai-Tibetan Plateau, Weed Res. 45, 114-120.

Dumas J.B.A. (1831) Procédés de l'analyse organique, Ann. Chim. Phys. 2, 198-213.

Eslami S.V., Gill G.S., Bellotti B., McDonald G. (2006) Wild radish (Raphanus raphanistrum) interference in wheat, Weed Sci. 54, 749-756.

FAO-UNESCO (1974) Soil map of the world, 1:5 000 000, FAO, Roma (Italy).

Ghaley B.B., Hauggaard-Nielsen H., Hogh-Jensen H., Jensen E.S. (2005) Intercropping of wheat and pea as influenced by nitrogen fertilization, Nutr. Cycl. Agroecosys. 73, 201-212.

Hartwig N.L., Ammon H.U. (2002) Cover crops and living mulches, Weed Sci. 50, 688-699.

Hashem A., Radosevich S.R., Roush M.L. (1998) Effect of proximity factors on competition between winter wheat (Triticum aestivum) and Italian ryegrass (Lolium multiflorum), Weed Sci. 46, 181-190.

Hauggaard-Nielsen H., Ambus P., Jensen E.S. (2001) Interspecific competition, $\mathrm{N}$ use and interference with weeds in pea-barley intercropping, Field Crop. Res. 70, 101-109. 
Hernánz J.L., Girón V.S., Cerisola C. (1995) Long-term energy use and economic evaluation of three tillage systems for cereal and legume production in central Spain, Soil Till. Res. 35, 183-198.

Jeuffroy M.-H., Bouchard C. (1999) Intensity and duration of nitrogen deficiency on wheat grain number, Crop Sci. 39, 1385-1393.

Jumpponen A., Hogberg P., Huss-Danell K., Mulder C.P.H. (2002) Interspecific and spatial differences in nitrogen uptake in monocultures and two-species mixtures in north European grasslands, Funct. Ecol. 16, 454-461.

Justes E., Jeuffroy M.H., Mary B. (1997) Wheat, barley, and durum wheat, in: Lemaire G. (Ed.), Diagnosis of the nitrogen status in crops, Springer-Verlag, Berlin Heidelberg, pp. 73-91.

Kinsella J. (1995) The effects of various tillage systems on soil compaction, in: Soil and Water Conservation Society (Ed.), Farming for a better environment, Ankeny, USA, pp. 15-17.

Lampurlanés J., Cantero-Martínez C. (2003) Soil bulk density and penetration resistance under different tillage and crop management systems and their relationship with barley root growth, Agron. J. 95, 526-536.

Lantinga E.A., Nassiri M., Kropff M.J. (1999) Modelling and measuring vertical light absorption within grass-clover mixtures, Agr. Forest Meteorol. 96, 71-83.

Nakamoto T., Tsukamoto M. (2006) Abundance and activity of soil organisms in fields of maize grown with a white clover living mulch, Agr. Ecosyst. Environ. 115, 34-42.

Olesen J.E., Hansen P.K., Berntsen J., Christensen S. (2004) Simulation of above-ground suppression of competing species and competition tolerance in winter wheat varieties, Field Crops Res. 89, 263-280.
Recous S., Machet J.-M., Mary B. (1992) The partitioning of fertilizer$\mathrm{N}$ between soil and crop - Comparison of ammonium and nitrate applications, Plant Soil 144, 101-111.

Sánchez-Gíron V., Serrano A., Hernánz J.L., Navarrete L. (2004) Economic assessment of three long-term tillage systems for rainfed cereal and legume production in semiarid central Spain, Soil Till. Res. 78, 35-44.

SAS Institute Inc. (1999) SAS OnlineDoc®, Version 8, SAS Institute Cary, NC.

Seavers G.P., Wright K.J. (1999) Crop canopy development and structure influence weed suppression, Weed Res. 39, 319-328.

Sinoquet H., Cruz P. (1993) Analysis of light interception and use in pure and mixed stands of Digitaria decumbens and Arachis pintoi, Acta Ecol. 14, 327-339.

Sinoquet H., Caldwell R.M. (1995) Estimation of light capture and partitionning in intercropping systems, in: Sinoquet H., Cruz P. (Eds.), Ecophysiology of tropical intercropping, INRA éditions, Paris, pp. 79-97.

Sinoquet H., Rakocevic M., Varlet-Grancher C. (2000) Comparison of models for daily light partitioning in multispecies canopies, Agr. Forest Meteorol. 101, 251-263.

Teasdale J.R. (1996) Contribution of cover crops to weed management in sustainable agricultural systems, J. Prod. Agr. 9, 475-479.

Tremmel D.C., Bazzaz F.A. (1995) Plant architecture and allocation in different neighborhoods - Implications for competitive success, Ecology 76, 262-271.

Vandermeer J.H. (1989) The ecology of intercropping, Cambridge University Press, Cambridge, UK.

Wallace J.S., Batchelor C.H., Dabeesing D.N., Teeluck M., Soopramanien G.C. (1991) A comparison of the light interception and water-use of plant and first ratoon sugar-cane intercropped with maize, Agr. Forest Meteorol. 57, 85-105. 